\title{
RENCANA PENATAAN KAWASAN DESTINASI WISATA PANTAI LASIANA KOTA KUPANG, PROVINSI NUSA TENGGARA TIMUR
}

\author{
Misella Maria Fransiska Dampung ${ }^{1)}$, Suryono Herlambang ${ }^{2)}$, Suryadi Santoso ${ }^{3)}$
}

1)Program Studi S1 PWK, Fakultas Teknik, Universitas Tarumanagara, misellaadampung@gmail.com

2)Program Studi S1 PWK, Fakultas Teknik, Universitas Tarumanagara, s.herlambang@gmail.com

3)Program Studi S1 PWK, Fakultas Teknik, Universitas Tarumanagara, josantosojkt@yahoo.com

\begin{abstract}
Abstrak
Pantai Lasiana adalah salah satu pantai di Kelurahan Lasiana, kecamatan Kelapa Lima, kota Kupang, Provinsi Nusa Tenggara Timur. Pemilihan kawasan Pantai Lasiana dikarenakan kawasan ini merupakan kawasan wisata yang menjadi icon Kota Kupang dengan keindahan alam (laut dan pantai) dan agrowisata (pohon lontar). Sebagai pantai unggulan, kebutuhan penunjang aktivitas wisata belum sesuai kebutuhan dan keinginan pengunjung. Penelitian ini bertujuan untuk perencanaan penataan kawasan wisata yang sesuai dengan potensi secara fisik, sosial dan budaya, dan ekonomi, serta kebutuhan dan keinginan pengunjung. Metode yang digunakan dalam penelitian ini adalah metode kuantitatif dan kualitatif. Memiliki 5(lima) konsep perencanaan yaitu pertama: mitigasi bencana ( rawan bencana tsunami dan gelombang pasang), kedua: pelestarian lingkungan (agrowisata: pohon lontar dan mangrove), ketiga: pengembangan pariwisata pantai (pembagian zona wisata pantai dan budaya), keempat: integrasi dan konektivitas dalam kawasan (sirkulasi kendaraan dan pengunjung), dan kelima: pengembangan kawasan strategis wisata pantai di pesisir Utara Kota Kupang. Dengan adanya penataan akan menghasilkan wujud Pantai Lasiana yang lebih baik. Beberapa analisis yang dilakukan yaitu analisis kebijakan/regulasi, analisis daya dukung lingkungan, analisis lokasi, analisis tapak, analisis competitiveness, analisis persepsi pengunjung, analisis best practice, analisis daya tarik wisata budaya di Kota Kupang, dan analisis kebutuhan ruang.
\end{abstract}

Kata kunci: kawasan wisata pantai; kegiatan olahraga pantai dan festival/event kesenian budaya; penataan.

\begin{abstract}
Lasiana Beach is one of the beaches in Lasiana Sub-district, Kelapa Lima District, Kupang City, East Nusa Tenggara Province. The selection of the Lasiana Beach area is because this area is a tourist area that has become an icon of Kupang City with natural beauty (sea and beach) and agro-tourism (palm trees). As a superior beach, the needs of supporting tourist activities do not match the needs and desires of visitors. This study aims to plan the arrangement of tourist areas that are in accordance with the physical, social and cultural, and economic potential, as well as the needs and desires of visitors. The method used in this research is quantitative and qualitative methods. Has 5 (five) planning concepts, namely first: disaster mitigation (prone to tsunamis and tidal waves), second: environmental preservation (agro-tourism: palm trees and mangroves), third: coastal tourism development (division of coastal and cultural tourism zones), fourth: integration and connectivity within the area (circulation of vehicles and visitors), and fifth: the development of strategic coastal tourism areas on the north coast of Kupang City. With the arrangement will produce a better form of Lasiana Beach. Some of the analyzes conducted are policy / regulatory analysis, environmental carrying capacity analysis, location analysis, site analysis, competitiveness analysis, visitor perception analysis, best practice analysis, analysis of the attractiveness of cultural tourism in the city of Kupang, and analysis of space requirements.
\end{abstract}

Keywords: beach tourism area; beach sports activities and cultural art festival/event; planning 


\section{PENDAHULUAN}

\section{Latar Belakang}

Kota Kupang merupakan Ibu kota Provinsi Nusa Tenggara Timur yang memiliki luas sebesar $180,27 \mathrm{~km}^{2}$ dan panjang pesisir $\pm 27 \mathrm{~km}$. Kawasan pesisir Kota Kupang merupakan awal perkembangan di Kota Kupang. Secara historis perkembangan kawasan pesisir Kota Kupang dikarenakan adanya potensi ekonomi dimana menjadi pusat perdagangan dan pariwisata. Kegiatan pariwisata yang ada di kawasan pesisir Kota Kupang, salah satunya Pantai Lasiana dengan letaknya yang strategis berada dekat pusat Kota Kupang yang berjarak $\pm 11 \mathrm{~km}$ dari Pusat Kota Kupang. Pantai Lasiana dikenal sebagai pantai seribu lontar dan saat ini menjadi pantai unggulan bagi masyarakat Kota Kupang. Luas Kawasan Pantai Lasiana sebesar 15,9 Ha. Pada tahun 1986, Pemerintah Provinsi Nusa Tenggara Timur membangun berbagai fasilitas wisata seperti gazebo, kolam renang, kantor pengelola, panggung hiburan, dan lainnya. Potensi yang dimiliki Pantai Lasiana adalah keindahan alam (laut dan pantai), agrowisata (pohon lontar), life style masyarakat (menyadap nira/lontar). Berdasarkan RIPPDA Provinsi NTT dan RTRW Kota Kupang, Pantai Lasiana masuk dalam Kawasan Strategis Pariwisata Pantai (KSPP) dan menjadi sektor unggulan dalam pengembangan kegiatan ekonomi kota dengan tetap memperhatikan aspek lingkungan pesisirnya. Sesuai rencana Pemerintah Kota Kupang, yang akan menjadikan Pantai Lasiana sebagai pantai unggulan dengan keindahan pantainya dan menonjolkan kebudayaan setempat maka terciptanya Taman Budaya Flobamora.

\section{Rumusan Masalah}

Kebutuhan penunjang aktivitas wisata seperti sarana prasarana dan atraksi wisata belum sesuai dengan kebutuhan dan keinginan pengunjung. Hal ini berdasarkan hasil wawancara dengan beberapa pengunjung, dikatakan bahwa atraksi yang ditawarkan di Pantai Lasiana masih kurang sehingga pengunjung lebih tertarik untuk datang ke pantai-pantai di sekitar Pantai Lasiana. Untuk itu, penulis membatasi diri pada kawasan Pantai Lasiana dimana belum adanya perencanaan mengenai pemenuhan kebutuhan aktivitas yang sesuai dengan keinginan dan kebutuhan pengunjung.

\section{Tujuan}

Membuat rencana penataan kawasan destinasi wisata Pantai Lasiana yang sesuai dengan potensi, kebutuhan dan keinginan pengunjung.

\section{KAJIAN LITERATUR}

Menurut Soekadijo (1996), syarat perencanaan produk wisata: 1) Atraksi; 2) Objek wisata terintegrasi dengan jasa pelayanan, transportasi, dan aktualisasi; 3) Strategi meningkatkan pengunjung. Menurut Bovy (1977), hal yang perlu diperhatikan dalam perencanaan produk wisata: 1) Riset pasar (market research), meliputi: luas area, penduduk, dan sosial ekonomi,dll; 2) Pengamatan lokasi (site investigation), meliputi: aksesibilitas, infrastruktur, dll; 3) Program, meliputi: persyaratan kebutuhan fasilitas; 4) Penataan fisik, meliputi: traffic, sirkulasi, dan transportasi. Menurut Fandeli (2002), kriteria penentuan kawasan wisata sebagai berikut:

Tabel 1. Kriteria Penentuan Kawasan Wisata

\begin{tabular}{ccc}
\hline Kriteria Fisik & $\begin{array}{c}\text { Kriteria Sosial, Ekonomi, dan } \\
\text { Budaya }\end{array}$ & Kriteria Hukum Kebijakan \& Perundangan \\
\hline Topografi & Daya tarik budaya \& tradisi & Rencana Tata Ruang Wilayah Setempat \\
\hline Arus dan gelombang & Daya dukung masyarakat & UU No. 9 Tahun 1990 Tentang Kepariwisataan \\
\hline Bentuk lahan & Nilai historis kawasan & UU No. 26 Tahun 2007 Tentang Penataan Ruang \\
\hline Ekosistem & & UU No. 5 Tahun 1990 Tentang Konservasi \\
\hline Vegetasi flora dan fauna & Norma-norma yang berlaku di lingkungan \\
& & setempat
\end{tabular}

Sumber: Chalid Fandelli \& Mukhlison, 2002 


\section{Komponen Pengembangan Kawasan}

Komponen-komponen yang perlu diperhatikan dalam pengembangan kawasan pantai pada dasarnya dipengaruhi oleh karakteristik dari demand dan supply industri kepariwisataan itu sendiri.

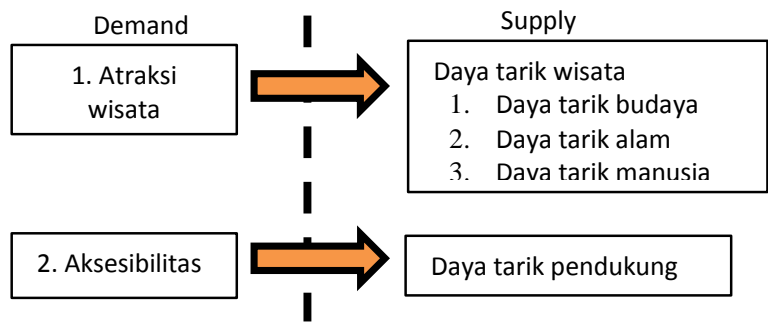

Gambar 1. Demand dan Supply Industri Kepariwisataan

Sumber: Perencanaan Kawasan Pantai Development Book, 2010

Tabel 2. Jenis-Jenis Wisata Pantai

\begin{tabular}{lll}
\hline Bentuk dan Karakter Elemen Pantai & Karakteristik & $\begin{array}{l}\text { Aksesibilitas dan Fasilitas } \\
\text { dalam Pantai }\end{array}$ \\
\hline Pantai berbukit pasir & Wisata alam & Pantai terpencil \\
\hline Pantai mangrove & Wisata buatan & Pantai pedesaan \\
\hline Pantai bertebing & Wisata seni budaya & Pantai lokal \\
\hline Pantai berkarang & & Pantai kota (urban) \\
\hline Pantai landai & & \\
\hline Pantai skeren & & \\
\hline
\end{tabular}

Sumber: Astuti, 2015 dan Zadel, 2015

Tabel 3. Faktor-Faktor yang Mempengaruhi Wisata

\begin{tabular}{llllll}
\hline $\begin{array}{l}\text { Jumlah } \\
\text { Pengunjung }\end{array}$ & $\begin{array}{l}\text { Kebiasaan } \\
\text { Pengunjung }\end{array}$ & Jarak Capai & $\begin{array}{l}\text { Elemen } \\
\text { Pantai }\end{array}$ & $\begin{array}{l}\text { Flora dan } \\
\text { Fauna }\end{array}$ & $\begin{array}{l}\text { Keadaan } \\
\text { Alam }\end{array}$ \\
\hline $\begin{array}{l}\text { Daya tarik } \\
\text { objek wisata }\end{array}$ & $\begin{array}{l}\text { Secara berkelompok } \\
\text { atau individu }\end{array}$ & $\begin{array}{l}\text { Efisiensi waktu yang } \\
\text { digunakan selama perjalanan }\end{array}$ & Ombak & Vegetasi & Hidrologi \\
\hline $\begin{array}{l}\text { Tersedianya } \\
\text { sarana dan } \\
\text { prasarana }\end{array}$ & $\begin{array}{l}\text { Tujuan untuk santai } \\
\text { atau sekedar duduk- } \\
\text { duduk }\end{array}$ & & Cakrawala & & Iklim \\
\hline & Wisata seni budaya & & & \\
\hline
\end{tabular}

Sumber: Zadel, 2015

Tabel 4. Kebutuhan Fasilitas

\begin{tabular}{ll}
\hline Menurut Obyeknya & Menurut Modelnya \\
\hline Perairan & $\begin{array}{l}\text { Ruang terbuka: taman bermain, area bernang, area memancing, area } \\
\text { rekreasi, gazebo }\end{array}$ \\
\hline Pantai & $\begin{array}{l}\text { Ruang tertutup: restaurant/cafe, kios souvenir, gardu pandang, ruang } \\
\text { administrasi/pengelola, mushola }\end{array}$ \\
\hline Daratan & Ruang service: parkir, toilet, ruang mekanikal elektrikal \\
\hline
\end{tabular}

Sumber: Zadel, 2015

\section{METODE}

Dalam penelitian menggunakan metode kuantitatif dan kualitatif. Metode kuantitatif digunakan dalam meniliti populasi dan sampel penelitian dimana teknik pengambilan sampel dilakukan dengan mengetahui jumlah pengunjung per hari. Kemudian metode kualitatif digunakan untuk melihat kondisi fisik maupun kegiatan atau aktivitas di kawasan penelitian. Untuk itu, populasi diambil dari perhitungan jumlah kendaraan roda dua dan roda empat, maka didapatlah sampel sebanyak 88 sampel. Serta sumber data primer dan data sekunder yang dikumpulkan dengan beberapa cara, yaitu: (1) Observasi, dilakukan untuk mempelajari secara langsung kondisi objek studi, meliputi keadaan fisik, kelengkapan sarana prasarana, (2) Wawancara, dilakukan kepada 
infroman terkait seperti, pengunjung dan pemerintah khususnya Dinas Pariwisata Provinsi NTT selaku pengelola kawasan Pantai Lasiana dan dinas-dinas terkait yang menunjang ketersediaan data yang dibutuhkan dalam penelitian, (3) Kuesioner, daftar pertanyaan tertulis yang disusun untuk diberikan kepada pengunjung mengenai daya tarik, serta kepuasan dan harapan tentang penataan Pantai Lasiana kedepan, (4) Dokumentasi, hasil foto atau bukti pada saat survei lapangan. Analisis yang digunakan adalah analisis kebijakan/regulasi, analisis daya dukung lingkungan, analisis lokasi, analisis tapak, analisis competitiveness, analisis persepsi pengunjung, analisis best practice, analisis daya tarik wisata di Kota Kupang, dan analisis kebutuhan ruang.

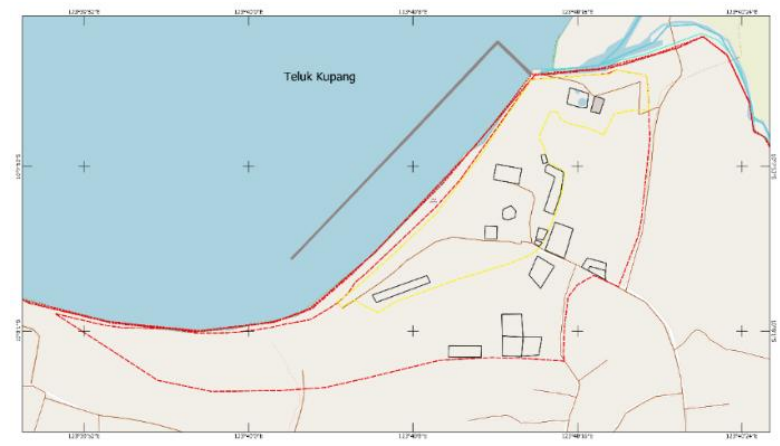

Gambar 2. Deliniasi Kawasan Pantai Lasiana Sumber: olahan penulis, 2020

Lokasi Pantai Lasiana terletak di Kelurahan Lasiana, Kecamatan Kelapa Lima, Kota Kupang, Provinsi Nusa Tenggara Timur. Jarak Pantai Lasiana terhadap pusat kota $\pm 11 \mathrm{~km}$ dan $\pm 6 \mathrm{~km}$ terhadap bandara. Pantai Lasiana memiliki luas sebesar 15,9 Ha dengan panjang garis pantai 864,12 meter. Berikut merupakan batas administrasinya:

- Utara: berbatasan dengan Teluk Kupang

- Timur: berbatasan dengan Kecamatan Tarus Kabupaten Kupang

- Selatan: berbatasan RT 05 dan RT 06 Kelurahan Lasiana

- Barat: berbatasan dengan Pantai Batu Nona

\section{DISKUSI DAN HASIL}

Regulasi/Kebijakan

RIPPDA Provinsi Nusa Tenggara Timur

Berdasarkan Perda No. Tahun 2015, Pantai Lasiana termasuk dalam Kawasan Strategis Pariwisata Provinsi, dimana bisa menjadi peluang sebagai tarikan pengunjung dari luar kota.

\section{Kebijakan RTRW Kota Kupang}

Berdasarkan rencana struktur ruang, sistem pelayanan kegiatan kota akan membentuk konsep waterfront city. Kemudian berdasarkan RDTR, Pantai Lasiana masuk dalam BWK III sebagai kawasan pariwisata. Berdasarkan RTRW, garis sempadan pantai sekitar 15 - $30 \mathrm{~m}$ dari titik pasang tertinggi. Namun, menurut peraturan Undang-Undang Kawasan Pesisir dan Pulau-Pulau Kecil, garis sempadan pantai harus berjarak $100 \mathrm{~m}$ dari titik pasang tertinggi untuk mencegah abrasi dan kerusakan laut.

\section{RPJMD Kota Kupang $2017-2022$}

Memiliki rencana program prioritas seperti, program penataan rute wisata, pengadaan sarana prasarana penunjang, dan jumlah pelaksanaan kegiatan/event dan program pembinaan ekonomi kreatif bagi masyarakat untuk mendukung sektor pariwisata.

\section{Proximity dan Aksesibilitas}

Lokasi kawasan Pantai Lasiana yang terletak di lokasi yang strategis karena berada dekat dengan jalan raya utama, akses ke bandara dan pusat kota yang mudah dicapai menggunakan kendaraan 
umum maupun pribadi dengan jarak $11 \mathrm{~km}$ dan $6 \mathrm{~km}$ menjadikan Pantai Lasiana sebagai salah satu alternatif kunjungan wisata bagi para turis lokal, domestik, dan internasional di Kota Kupang. Untuk pencapaian ke area Pantai Lasiana dengan menggunakan kendaraan umum harus menempuh jarak \pm 500 meter dengan berjalan kaki melewati jalan perumahan penduduk dari pintu gerbang kawasan Pantai Lasiana.

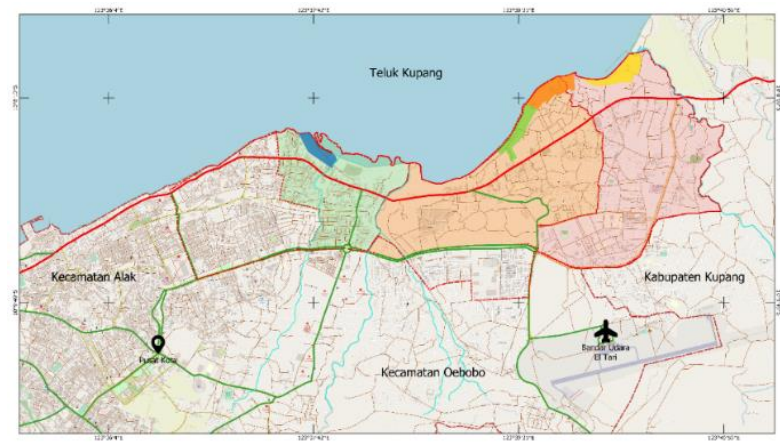

Gambar 3. Aksesibilitas dan Proximity Sumber: Olahan penulis, 2020

Di sekitar Pantai Lasiana, terdapat 3 wisata pantai yaitu Pantai Paradiso, Pantai Nunsui, dan Pantai Batu Nona. Untuk itu, diperlukan strategi dalam mengembangkan Pantai Lasiana sehingga terciptanya aktivitas/kegiatan pantai yang berbeda dengan yang lainnya. Untuk itu, didapatlah hasil berdasarkan aspek peruntukkan lahan, mengoptimalkan penataan sesuai dengan karakteristik pantai. Serta, aspek rencana pengembangan lahan, sebagai kawasan festival budaya dengan keindahan pantai dan pohon lontar membutuhkan area event, wisata air/laut, dermaga, dan vegetasi lontar.

\section{Daya Dukung Lingkungan}

Memiliki resiko bencana tsunami sedang dan rendah dengan ketinggian genangan 1-3 meter dan Pada Februari 2014, Pantai Lasiana pernah dilanda gelombang tinggi sebesar $3-5 \mathrm{~m}$ dikarenakan angin musim barat. Untuk mencegah terjadinya kembal hal tersebut maka solusi dari Dinas PUPR Provinsi NTT adalah membuat tanggul penahan gelombang.

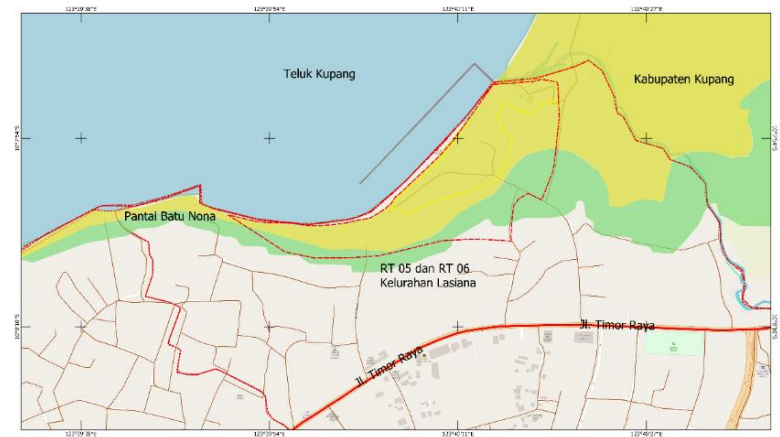

Gambar 4. Zona Rawan Bencana Tsunami

Sumber: Pusat Vulkanologi dan Mitigasi Bencana Geologi, 2019
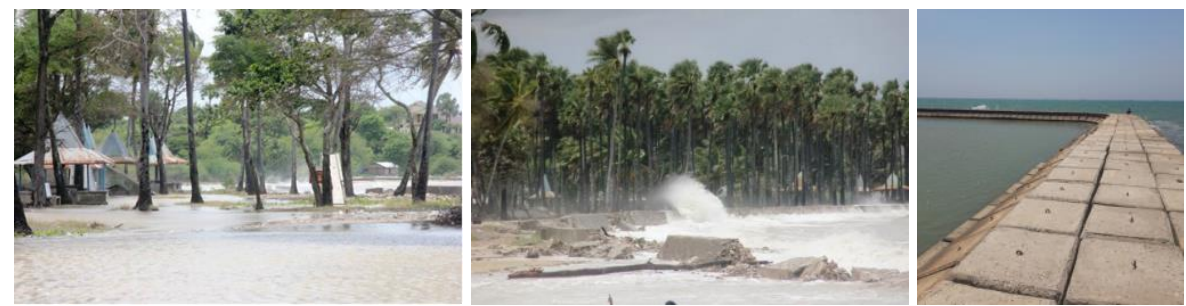

Gambar 5. Gelombang Tinggi pada Februari 2014 dan Tanggung Penahan Gelombang Sumber: Satker Pelaksanaan Jaringan SDA Dinas PUPR, 2014 dan Survei Lapangan, 2019 


\section{Topografi}

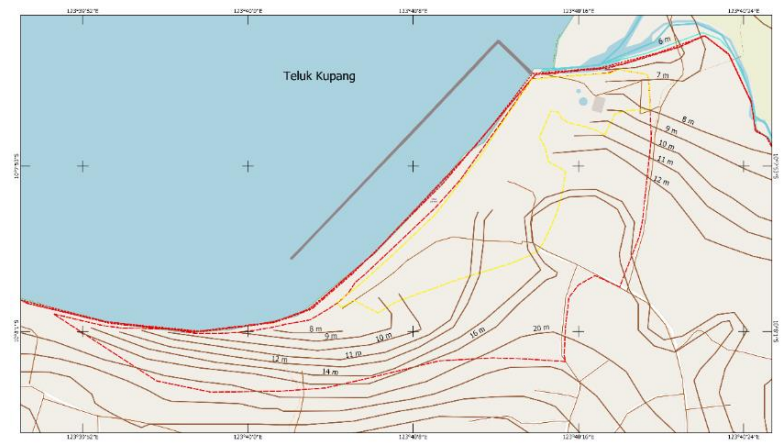

Gambar 6. Topografi Pantai Lasiana

Sumber: Kementerian PUPR, 2019

Pantai Lasiana berada di wilayah dengan ketinggian $20 \mathrm{mdpl}$, dengan kelerangan $0-8 \%$. Hal ini merupakan potensi apabila ingin melakukan penataan karena tingkat kelerengan cenderung landai dan memudahkan dalam melakukan pembangunan sarana dan prasarana pendukung aktivitas wisata. Namun, dikarenakan kelerengannya yang landai dan berada di garis pantai dapat beresiko terkena banjir rob dan tsunami. Hal ini bisa diatasi dengan melakukan pembangunan pembatas bibir pantai.

\section{Hidrologi}

Kondisi hidrologi di Pantai Lasiana terdapat sumur bor/sumur yang menhasilkan air tawar dalam dan sumur gali/dangkal yang menghasilkan air payau. Perlu adanya fasilitas PDAM (Perusahaan Daerah Air Minum) dalam alternatif pengadaan air tawar dan fasilitas bak penampung air untuk mencegah minimnya pelayanan air tawar dari sumur bor dan adanya metode Reverse Osmosis (RO) untuk melakukan pemurnian air dari air payau menjadi air tawar/air baku.

\section{Kondisi Tapak Pantai Lasiana}

Bentuk Tapak

Bentuk tapak Pantai Lasiana dengan luas 15,9 Ha, masih kurang ideal sehingga perlu mengambil lahan di area sebelah Timur yaitu muara sungai sebesar 0,3 Ha menjadi 16,2. Dapat menjadi daya tarik baru yaitu wisata pantai dan muara sungai.

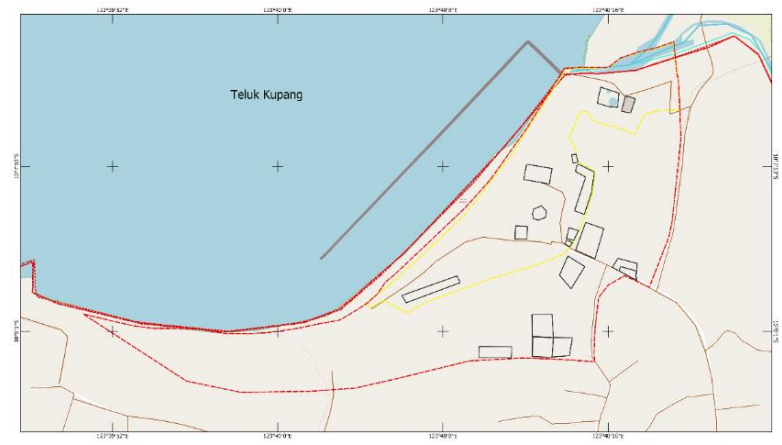

Gambar 7. Bentuk Tapak Pantai Lasiana

Sumber: Olahan Penulis, 2019

\section{Penggunaan Lahan}

Kawasan wisata pantai dengan luas 5,6 Ha, fasilitas (panggung pentas, toilet dan ruang bilas, tempat karaoke, pos jaga) dengan luas $0,2 \mathrm{Ha}$, area kuliner dengan luas $0,89 \mathrm{Ha}$, cafe dengan luas $0,02 \mathrm{Ha}$, permukiman dengan luas, $1 \mathrm{Ha}$, waduk dengan luas $0,41 \mathrm{Ha}$, pasir putih dengan luas 2,2 $\mathrm{Ha}$, lahan kosong dengan luas $5,7 \mathrm{Ha}$, dan sungai dengan luas $0,3 \mathrm{Ha}$. 


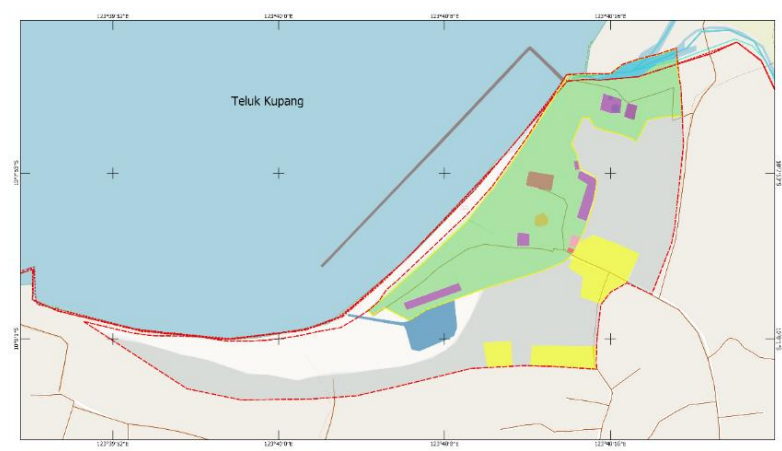

Gambar 8. Peta Penggunaan Lahan Pantai Lasiana Sumber: Olahan penulis, 2019
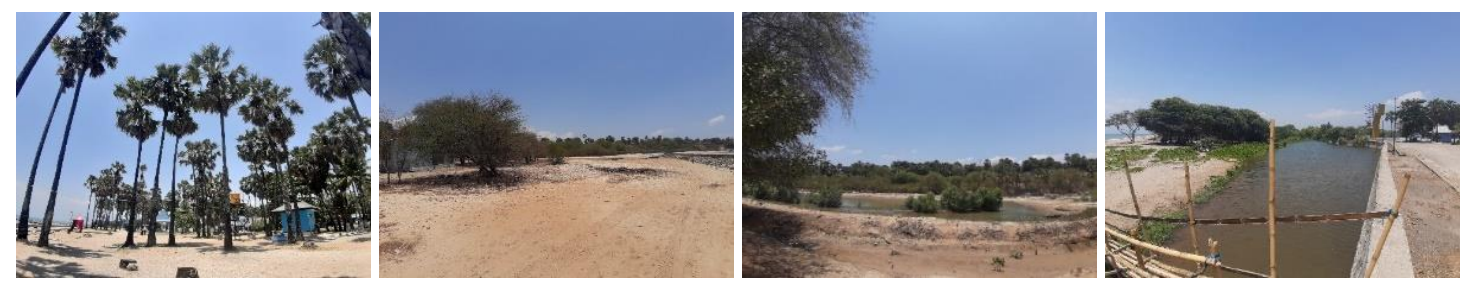

Gambar 9. Kondisi Penggunaan Lahan Pantai Lasiana

Sumber: Survey Lapangan, 2019

\section{Sirkulasi Kendaraan dan Pengunjung}

Pantai Lasiana memiliki 1 pos jaga, 2 area parkir dan dua jalan utama. Dalam penelitian ini, dilakukan perencanaan untuk mengintegrasikan antara kawasan wisata yang saat ini sudah berjalan dengan perencanaan yang telah ditetapkan RTRW Kota Kupang.

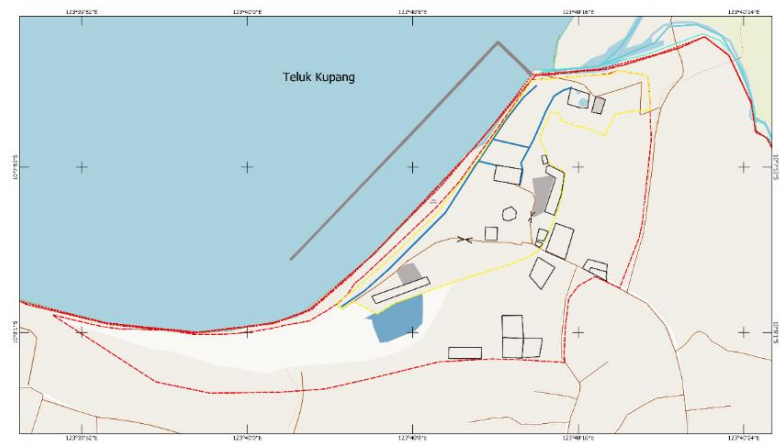

Gambar 10. Sirkulasi Kendaraan dan Pengunjung

Sumber: Olahan penulis, 2019
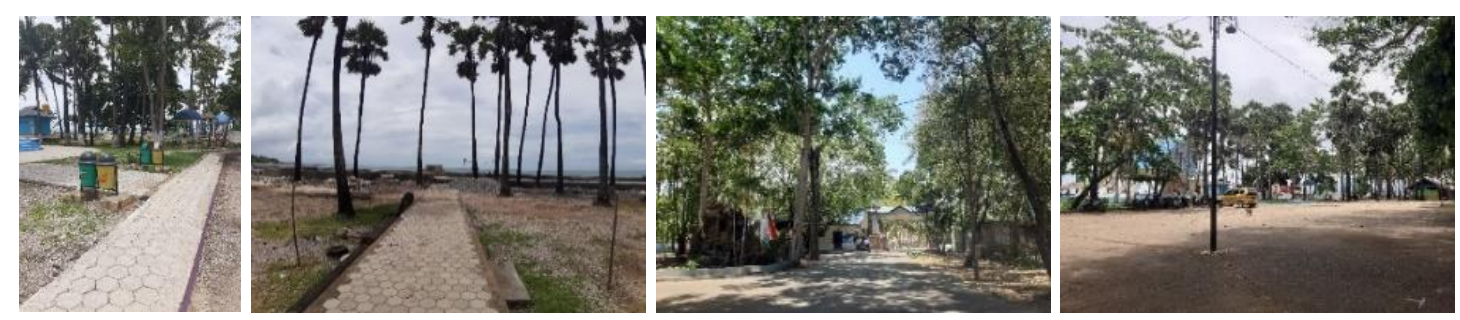

Gambar 11. Kondisi Jalan Sirkulasi

Sumber: Survey lapangan, 2019

\section{Sarana}

Berdasarkan hasil analisis, untuk fasilitas lopo/gazebo, toilet dan ruang bilas, serta panggung pentas merupakan fasilitas yang harus diperbaiki dan ditambahkan karena kondisi dan jumlah 
masih minim. Kemudian, untuk tempat kuliner perlu dikembangkan lagi dengan menambahkan makanan hasil laut seperti ikan bakar dan makanan khas Kupang seperti daging sei.

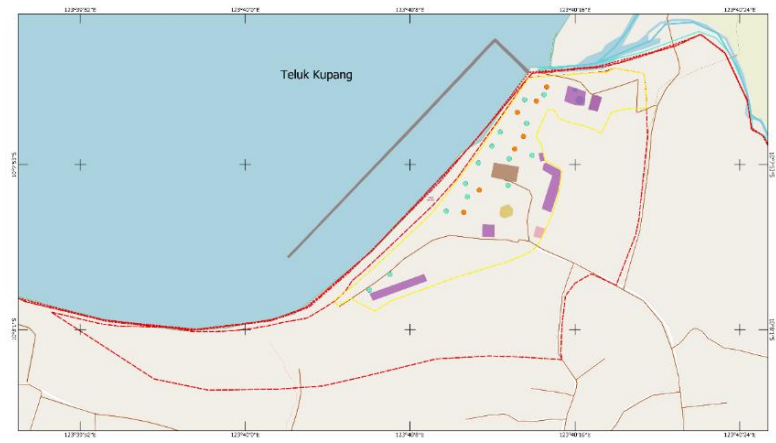

Gambar 12. Persebaran Sarana di Pantai Lasiana Sumber: Olahan penulis, 2019
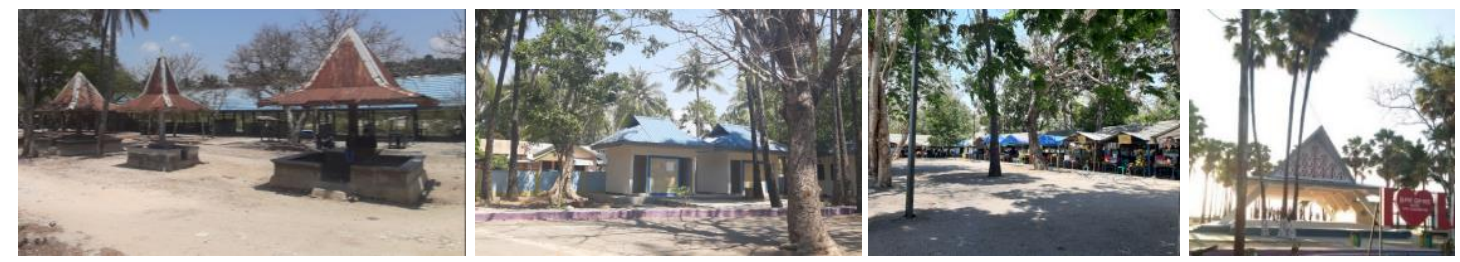

Gambar 13. Kondisi Sarana di Pantai Lasiana

Sumber: Survey lapangan, 2019

\section{Prasarana}

Berdasarkan hasil analisis, sistem keamanan dan kebersihan telah memadai, namun jaringan air bersih dan listrik perlu ditingkatkan dengan bak penampungan air dan penerangan lampu jalan. Untuk jalan perlu diperhatikan lagi oleh pemerintah dan dinas terkait karena menyangkut kenyamanan pengunjung.

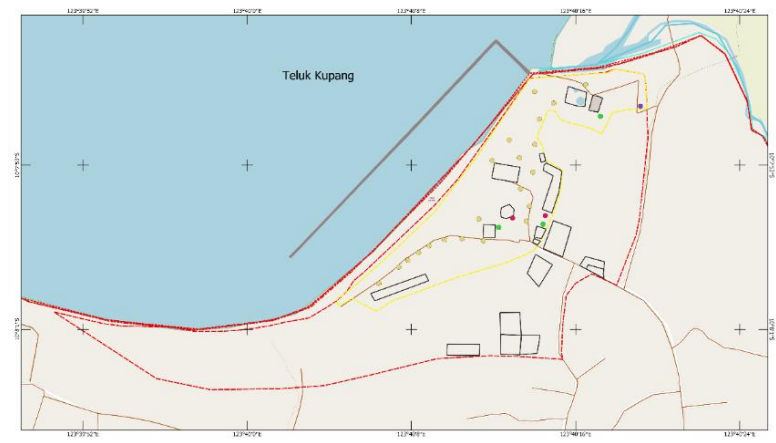

Gambar 14. Lokasi Prasarana di Pantai Lasiana Sumber: Olahan penulis, 2019
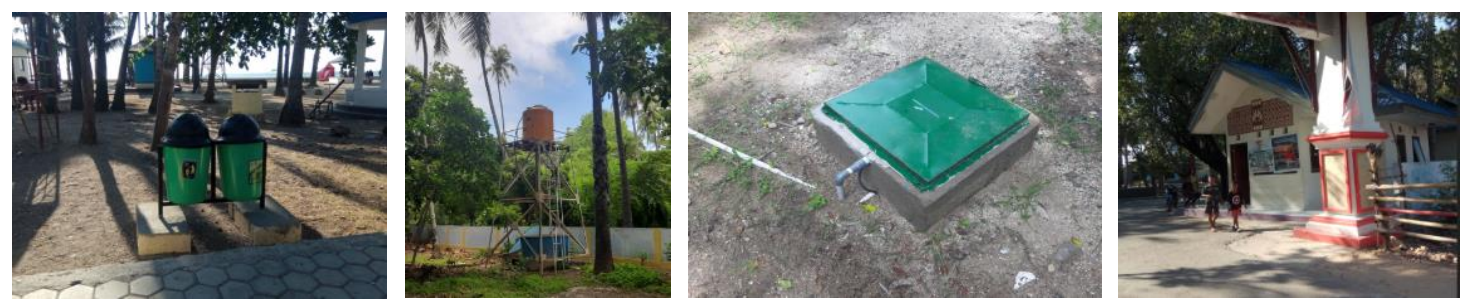

Gambar 15. Kondisi Prasarana di Pantai Lasiana Sumber: Survey lapangan, 2019 

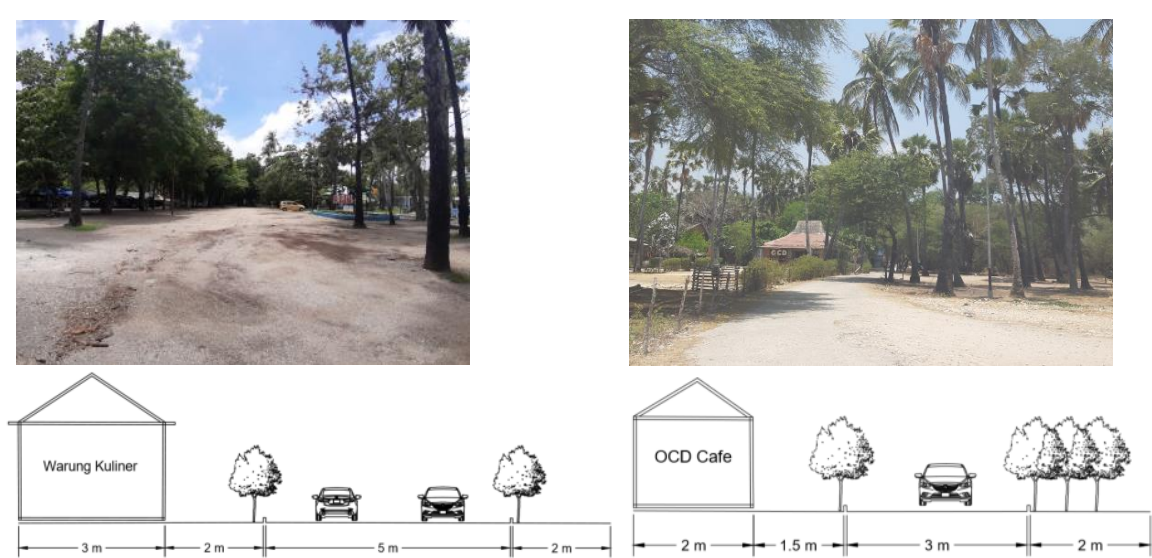

Gambar 16. Kondisi Jalan dan Potongan Jalan dalam Pantai Lasiana Sumber: Olahan penulis, 2019

\section{Jumlah Pengunjung Pantai Lasiana}

Tabel 5. Jumlah Pengunjung Tahun $2014-2018$

\begin{tabular}{ccccc}
\hline No & Tahun & Nusantara & $\begin{array}{c}\text { Jumlah } \\
\text { Lokal }\end{array}$ & Anak-Anak \\
\hline 1. & 2014 & 3620 & 3585 & 790 \\
\hline 2. & 2015 & 3940 & 3800 & 810 \\
\hline 3. & 2016 & 4405 & 4250 & 830 \\
\hline 4. & 2017 & 4635 & 4613 & 875 \\
\hline 5. & 2018 & 4970 & 4760 & 902 \\
\hline
\end{tabular}

Sumber: Dinas Pariwisata dan Ekonomi Kreatif Prov. NTT, 2019

\section{Daya Tarik Wisata Pantai}
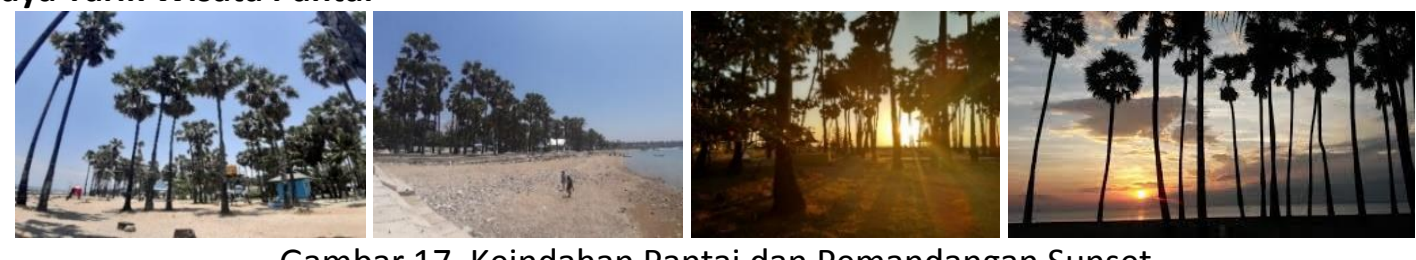

Gambar 17. Keindahan Pantai dan Pemandangan Sunset Sumber: Dokumentasi pribadi, 2019
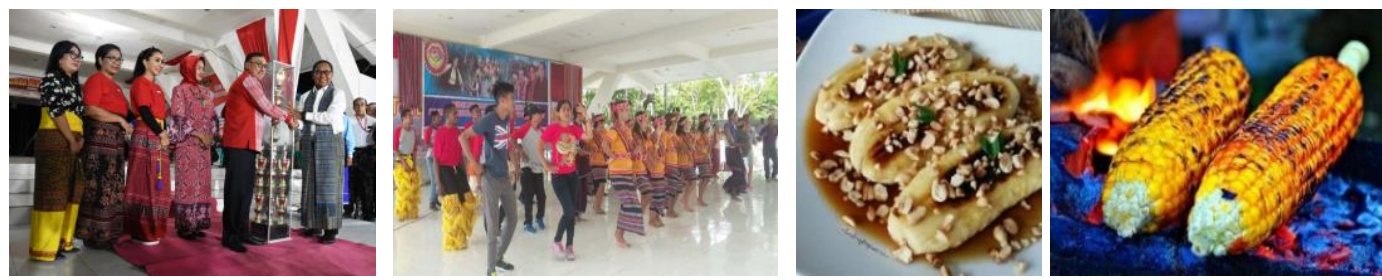

Gambar 18. Festival atau Event dan Kuliner Sumber: Dokumentasi pribadi, 2019

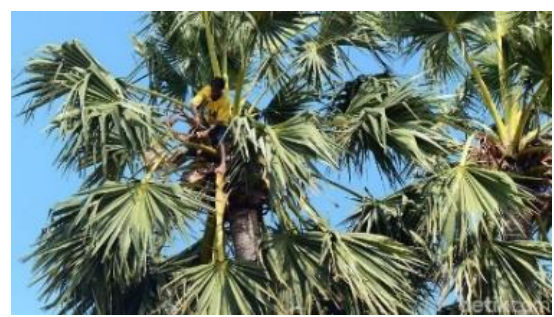

Gambar 19. Kegiatan Penyadapan Pohon Lontar Sumber: Google Image, 2019 


\section{Persepsi Pengunjung}

Berdasarkan hasil kuesioner, fasilitas yang perlu ditambahkan adalah ATM, pusat souvenir, tempat kuliner, taman, tempatpenyimpanan alat olahraga air, lapangan sport beach, jalur pedestrian, jalur sepeda, jogging track, atraksi (air, pantai, darat), dan tempat pengolahan pohon lontar.

\section{Tingkat Kepentingan dan Kepuasan}

Berdasarkan aspek lokasi dan aksesibilitas, fasilitas umum, fasilitas wisata, prasarana, serta peraturan dan kebijakan. Maka, dibuatlah diagram kartesius untuk menentukkan prioritas dalam perencanaan. Hasilnya terlihat dalam Gambar 20. Dari beberapa aspek, dikembangkan dalam diagram kartesius sehingga didapatkan hasil yang termasuk dalam kuadran I (diperhatikan) yaitu: Transportasi, Kedekatan dengan sarana transportasi, Toilet dan ruang bilas, Parkir, Lopo/gazebo, Panggung hiburan, Rekreasi air dan pantai, Jaringan air bersih, Pengelolaan.

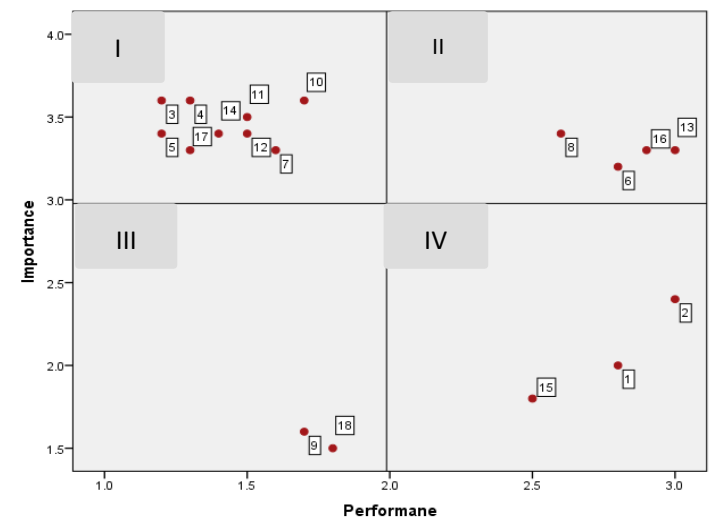

Gambar 20. Diagram Kartesius

Sumber: Olahan penulis, 2020

\section{Best Practice}

Objek pembanding dalah Pantai Kemala di Balikpapan dan Pantai Cenang di Lengkawi, Malaysia. Alasan mengambil kedua pantai tersebut adalah terletak di tengah kota dengan luas yang mendekati Pantai Lasiana. beberapa atraksi wisata yang ditawarkan kedua pantai tersebut adalah permainan olahraga air, area open space, dan fasilitas penunjang lainnya. Beberapa hal yang perlu diperhatikan dalam perencanaan berdasarkan best practice adalah:

a. Tepian air: Bangunan-bangunan penunjang seperti lopo perlu ditambah serta bangunan yang telah ada saat ini perlu diperbaiki.

b. Dermaga: Dermaga kayu digunakan sebagai tempat pemberhentian wisata air paddle boat, banana boat, dan jet ski untuk mendukung atraksi air.

c. Ruang terbuka (open space): Perlu dikembangkan taman dan plaza mengikuti promenade (tempat pejalan kaki) maupun jogging track yang akan dibangun nantinya.

d. Fasilitas penunjang: Taman bermain anak, jogging track, area untuk riverwalk, fasilitas sport water

\section{Konsep dan Perencanaan}

Mitigasi dan Adaptasi Bencana Tsunami

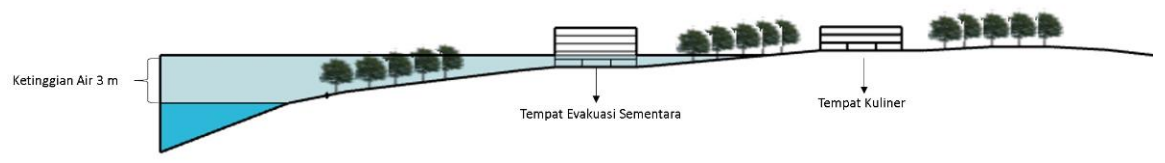

Gambar 21. Penempatan Tempat Evakuasi Sementara (TES)

Sumber: Olahan penulis, 2020 


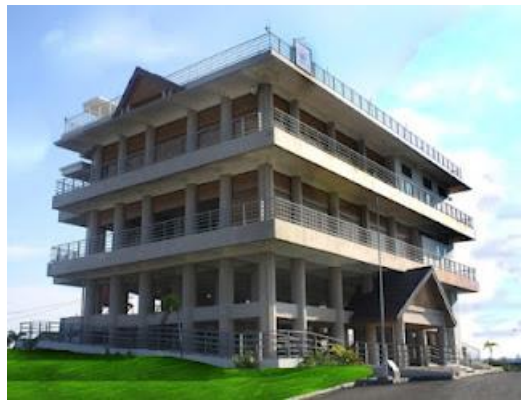

Gambar 22. Visualisasi Tempat Evakuasi Sementara

Sumber: bandaacehkota.go.id, 2020

\section{Pelestarian Lingkungan}

\section{Konsep Perencanaan}

1. Pada area GSP $100 \mathrm{~m}$ diarahkan seminimal mungkin adanya bangunan dan digunakan sebagai area hijau.

2. Kawasan yang memiliki fungsi khusus sebagai penahan erosi pantai seperti adanya batuan karang dan tanaman bakau

3. Sebagai area konservasi pohon lontar

Sumber: Olahan penulis, 2020

\section{Pengembangan Pariwisata}

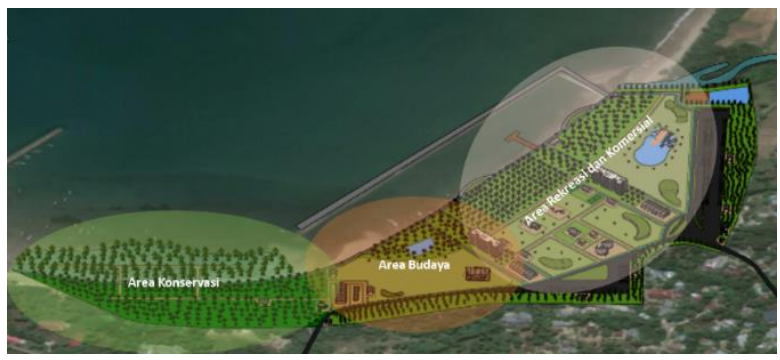

Gambar 24. Pembagian Area Zonasi

Sumber: Olahan penulis, 2020

Tabel 6. Konsep Pengembangan Pariwisata berdasarkan Area Zonasi

\begin{tabular}{|c|c|c|}
\hline Area Zonasi & Konsep Perencanaan & Gambar Konsep \\
\hline Area Rekreasi & $\begin{array}{l}\text { 1. Menikmati keindahan alam dengan } \\
\text { lopo/gazebo dan anjungan yang tersedia. } \\
\text { 2. Terdapat } 2 \text { jenis rekreasi, yaitu rekreasi } \\
\text { tertutup (berbayar), seperti waterboom. } \\
\text { Kemudian, rekreasi terbuka, seperti } \\
\text { fasilitas olahraga (lapangan sport beach } \\
\text { dan area skateboard), serta taman } \\
\text { bermain anak. } \\
\text { 3. Sport water. Jenis olahraga seperti, } \\
\text { banana boat, paddle boat, dan jet ski }\end{array}$ & \\
\hline $\begin{array}{l}\text { Area Rekreasi } \\
\text { dan Lindung }\end{array}$ & $\begin{array}{l}\text { 1. Kegiatan ekowisata atau lebih dikenal } \\
\text { dengan konservasi bertujuan untuk } \\
\text { memberikan pengetahuan pada } \\
\text { wisatawan untuk menjaga dan } \\
\text { melestarikan ekosistem pantai dan laut } \\
\text { 2. Adanya jalur pedestrian dan jalur sepeda }\end{array}$ & \\
\hline
\end{tabular}


Area Zonas

Area Budaya

\section{Konsep Perencanaan}

1. Terdapat panggung hiburan yang digunakan untuk pementasan kesenian budaya

2. Terdapat open space yang digunakan untuk pameran tenun ikat dan pameran pembangunan.

3. Tersedia makanan dan minuman berciri khas Kupang, seperti daging sei, ikan bakar, minuman buah siwalan, dan lain sebagainya dan pusat souvenir kerajianan

\section{Area Komersial \\ 1. Tersedia kuliner dengan jenis makanan} umum dan tradisional (ciri khas Kupang).

2. Tersedia tempat souvenir yang menjual hasil pengolahan pohon lontar dan sumber daya alam lainnya.

3. Restaurant/cafe dan tempat karaoke

4. ATM
Gambar Konsep
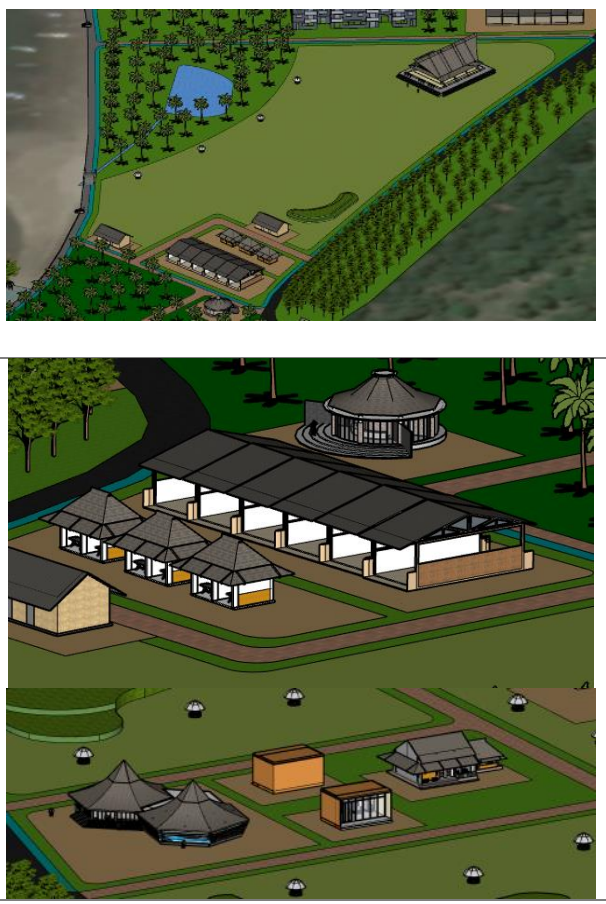

Sumber: Olahan penulis, 2020

Proyeksi jumlah pengunjung pada tahun 2028 sebesar 58.508 jiwa. Jumlah tersebut sudah ditambah dengan jumlah pengunjung pada saat festival/event. Untuk itu, didapatlah jumlah pengunjung per hari sebesar 160 jiwa, jumlah ini digunakan untuk menghitung kebutuhan ruang fasilitas penunjang. Hasilnya adalah sebagai berikut:

Tabel 7. Kebutuhan Ruang Fasilitas Penunjang

\begin{tabular}{cccccc}
\hline \multirow{2}{*}{ Zona } & Fasilitas & Luas & Jumlah & Sumber \\
& Area parkir & 34519,72 & 3,4 & & Kemenpar \\
\hline & Kantor pengelola & 112 & 0,0112 & 1 & Kemenpar \\
\hline Rekreasi, budaya & Toilet dan ruang bilas & 281,6 & 0,0281 & 16 & Ernst Neufert \\
\hline Komersial & Restoran dan kafe & 224 & 0,0224 & 1 & Kemenpar \\
\hline Komersial & Warung kuliner & 504 & 0,0504 & 18 & Penulis \\
\hline Komersial & Pusat souvenir & 168 & 0,0168 & 5 & Penulis \\
\hline Komersial & ATM center & 50,4 & 0,005 & 2 & Penulis \\
\hline Rekreasi & Gazebo & 160 & 0,0160 & 16 & Kemenpar \\
\hline Budaya & Pos jaga & 98 & 0,0098 & 2 & Penulis \\
\hline Komersial & Area panggung pentas & 20000 & 2 & 1 & Kemenpar \\
\hline Rekreasi dan lindung & Tempat karaoke & 211,4 & 0,0211 & 1 & Penulis \\
\hline Rekreasi & Tempat pengolahan pohon lontar & 210 & 0,021 & 1 & Penulis \\
\hline Rekreasi & Tempat evakuasi bencana tsunami & 720 & 0,072 & 2 & Penulis \\
\hline Rekreasi & Tempat penyimpanan alat olahraga & 688,97 & 0,0688 & 1 & Penulis \\
\hline Rekreasi & air & & & & \\
\hline Rekreasi & Menara pandang & 28 & 0,0028 & 1 & Penulis \\
\hline Rekreasi & Lapangan sport beach & 384 & 0,0384 & 3 & Delvatinson \\
\hline Rekreasi & Dermaga & 128 & 0,0128 & & Kemenpar \\
\hline Rekreasi & Area bermain anak & 8100 & 0,81 & & Penulis \\
\hline Total Kebutuhan Ruang Fasilitas & 8100 & 0,81 & & Penulis \\
\hline Area skateboard & $\mathbf{9 0 8 8 8 , 0 9}$ & $\mathbf{9}$ & & Penulis \\
\hline
\end{tabular}

Sumber: Olahan Penulis, 2020 


\section{Prasarana Air Bersih}

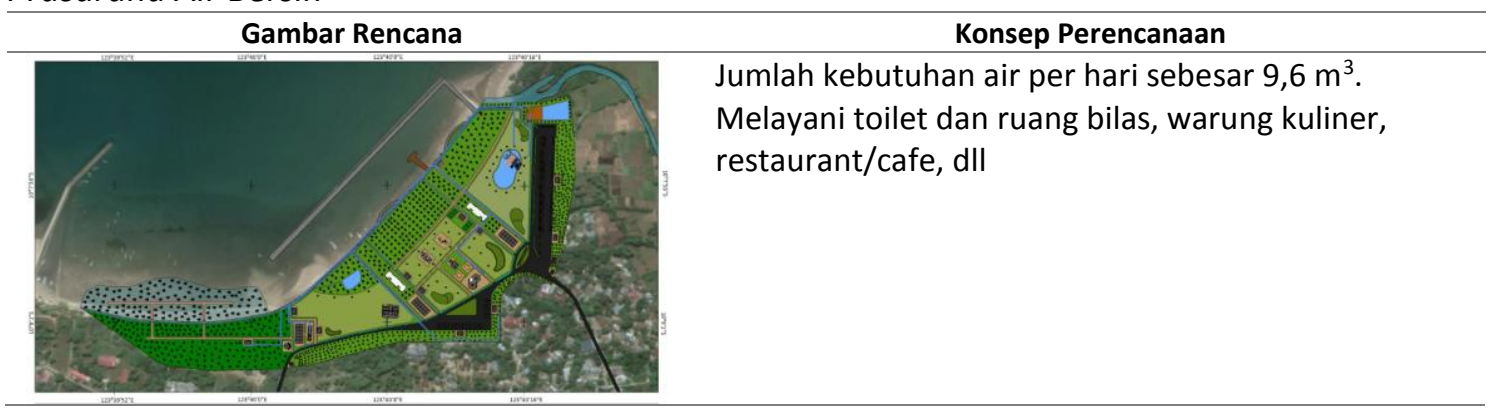

Sumber: Olahan penulis, 2020

\section{Peningkatan Konektivitas dan Integrasi dalam Kawasan}

1. Sirkulasi kendaraan: jalur akses dari pintu masuk kawasan menuju area parkir dan sebagai jalur pergerakan untuk pindah ke area lainnya.

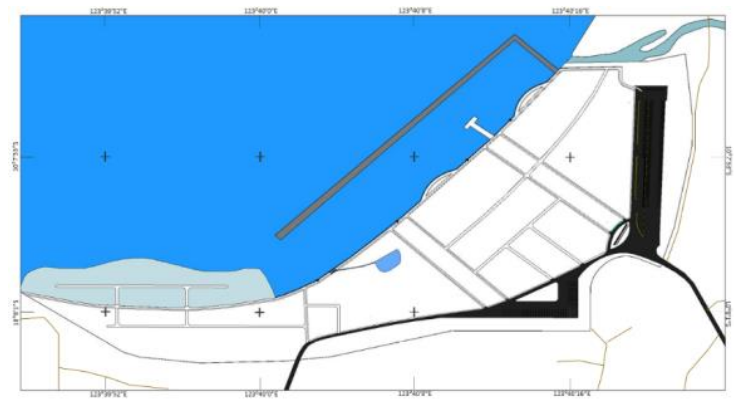

Gambar 27. Jalan Utama ROW 5 meter

Sumber: Olahan Penulis, 2020

2. Sirkulasi pengunjung: berupa jalur pedestrian yang menghubungkan beberapa area pusat kegiatan dalam tapak, serta terdapat jalur sepeda di sekitar area pedestrian yang mengililingi tiap zona.
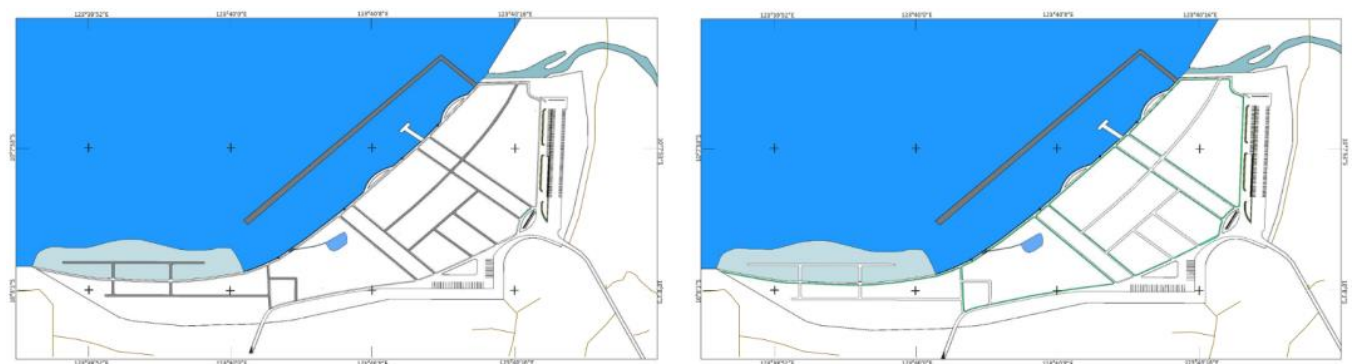

Gambar 28. Jalur Pedestrian ROW 3,5 m (kiri); Jalur Sepeda ROW 1,5 m (kanan) Sumber: Olahan Penulis, 2020

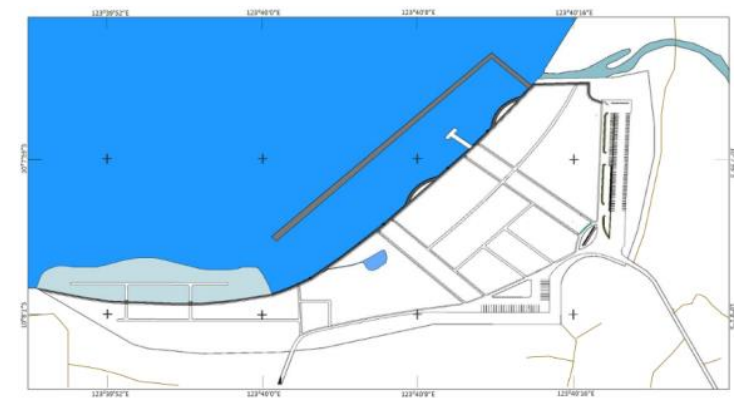

Gambar 30. Jogging Track ROW 4 meter Sumber: Olahan Penulis, 2020 
Pembuatan jogging track di tepi pantai dikarenakan hasil kusioner pengunjung yang mengatakan bahwa, salah satu aktivitas pengunjung yang sering dilakukan adalah menikmati keindahan pantai dengan adanya anjungan dan jogging track di tepi pantai.

\section{Pengembangan Kawasan Strategis}

Fokus pengembangan wisata pantai di kawasan pesisir Utara Kota Kupang, sehingga dapat dilakukan perencanaan yang mendukung pengembangan tersebut:

Tabel 8. Pengembangan Kawasan Strategis Wisata Pantai

\begin{tabular}{ccll}
\hline No. & \multicolumn{1}{c}{ Wisata Pantai } & \multicolumn{1}{c}{ Karakteristik } & \multicolumn{1}{c}{ Rencana Pengembangan } \\
\hline 1. & Pantai Paradiso & $\begin{array}{l}\text { Wisata pantai dan } \\
\text { Mangrove }\end{array}$ & $\begin{array}{l}\text { Perencanaan dengan fasilitas seperti, } \\
\text { jogging track, anjungan, balai konservasi } \\
\text { mangrove, galleri amngrove, dan tracking } \\
\text { wisata mangrove, bangunan komersial }\end{array}$ \\
\hline 2. & Pantai Nunsui & Wisata pantai dan & $\begin{array}{l}\text { Dermaga kapal, pasar ikan, anjungan, } \\
\text { bangunan komersial }\end{array}$ \\
\hline 3. & Pantai Batu Nona & Wisata sejarah & $\begin{array}{l}\text { Perencanaan terhadap makam rambut, } \\
\text { bangunan komersial }\end{array}$ \\
\hline 4. & Pantai Lasiana & $\begin{array}{l}\text { Wisata pantai, } \\
\text { agrowisata (pohon } \\
\end{array}$ & lontar), dan festival \\
& budaya & $\begin{array}{l}\text { Perencanaan rekreasi pantai, jalur } \\
\text { rekreasi (pedestrian dan sepeda), area } \\
\text { event serta kuliner khas Kupang }\end{array}$ \\
\end{tabular}

Sumber: RTBL Kawasan Strategis Pantai Oesapa dan Olahan Penulis, 2020

\section{KESIMPULAN DAN SARAN \\ Kesimpulan}

Pantai Lasiana memiliki potensi yang bisa dikembangkan, baik secara fisik terletak di lokasi yang strategis dan dekat dengan pusat kota dan bandara. Secara sosial dan budaya, digunakan sebagai tempat wisata unggulan yang menampilkan keindahan alam dan kesenian budaya. Secara ekonomi, kegiatan masyarakat setempat yaitu menyadap pohon lontar yang ada di Pantai Lasiana bisa menambah penghasilan dan kreativitas dalam mengolah hasil sumber daya alam. Kawasan Pantai Lasiana perlu adanya ketersediaan sarana prasarana dan atraksi/kegiatan yang ditawarkan untuk meningkatkan jumlah pengunjung. Hal ini didasarkan pada kebutuhan dan keinginan pengunjung. Rencana Penataan Pantai Lasiana perlu memperhatikan lima lapisan konsep perencanaan. Lapis pertama menjadi dasar untuk peencanaan selanjutnya yaitu mitigasi dan adaptasi bencana tsunami, lapis kedua yaitu pelestarian lingkungan, lapis ketiga yaitu pengembangan pariwisata, lapis keempat yaitu peningkatan konektivitas dan integrasi dalam kawasan, dan lapis kelima yaitu pengembangan kawasan strategis.

\section{Saran}

a. Dalam suatu wisata pantai, Pemerintah setempat perlu membahas dan mengkaji unsur keterkaitan stakeholder atau pihak swasta dalam perencanaan agar kawasan Pantai Lasiana terlihat lebih menarik.

b. Dinas Pariwisata dan Kebudayaan setempat perlu melihat kebutuhan dan keinginan pengunjung dari segi sarana maupun prasarana dan perlu evaluasi tiap tahunnya untuk melihat kinerja dalam pengelolaan dan perencanaan.

c. Untuk masyarakat sekitar, perlu adanya kerjasama dalam membantu menjaga dan merawat sarana prasarana yang ada dan mendukung kawasan Pantai Lasiana dari segi ekonomi kreatif maupun ativitas yang dapat menarik pengunjung. 


\section{REFERENSI}

Astuti, T. (2015). Buku Pedoman Umum Geografi. Jakarta: Vicosta Publishing.

Bovy, M. B. (1977). Tourism and Recreation Development Boston. CBI Publishing Company.

Fandeli, C. (2002). Pengusahaan Ekowisata. Yogyakarta: Fakultas Kehutanan UGM.

Soekadijo, R. G. (1996). Anatomi Pariwisata. Jakarta: PT. Gramedia Pustaka Utama.

Zrinka Zadel, P. (2015). Beaches in the Function of Primary Resource of the Beach Tourism Product.

Peraturan Menteri Pariwisata Republik Indonesia Nomor 3 Tahun 2018 Tentang Petunjuk Operasional Pengelolaan Dana Alokasi Khusus Fisik Bidang Pariwisata

Peraturan Pemerintah Daerah : Rencana Tata Ruang Wilayah Kota Kupang

Peraturan Pemerintah Daerah : Rencana Induk Pariwisata Daerah Provinsi Nusa Tenggara Timur

Peraturan Menteri PU No. 06/PRT/M/2007 Tentang Pedoman Umum Rencana Tata Bangunan dan Lingkungan (RTBL)

Undang - Undang Republik Indonesia No. 26 Tahun 2007 Tentang Penataan Ruang Wilayah Nasional 
